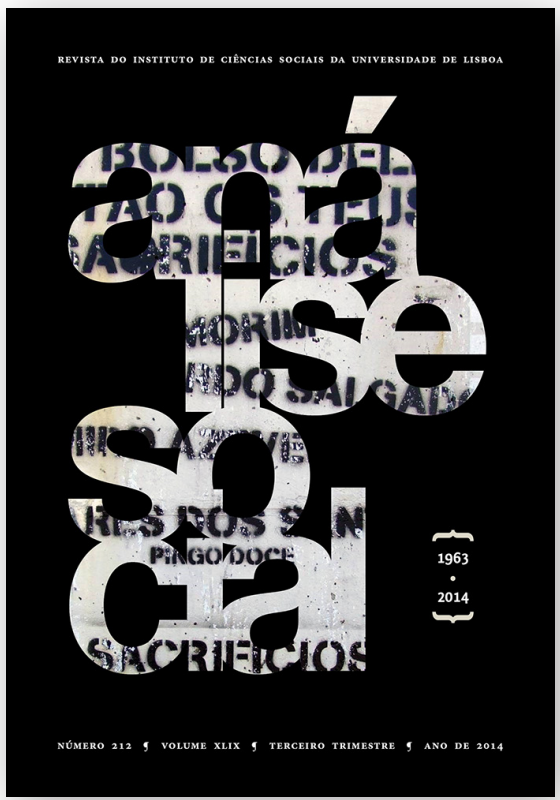

INTERVIEW WITH

GÖRAN THERBORN

\title{
The killing fields of inequality
}

by Sofia Aboim

Análise Social, 212, XLIX $\left(3 .^{\circ}\right), 2014$

ISSN ONLINE 2182-2999 


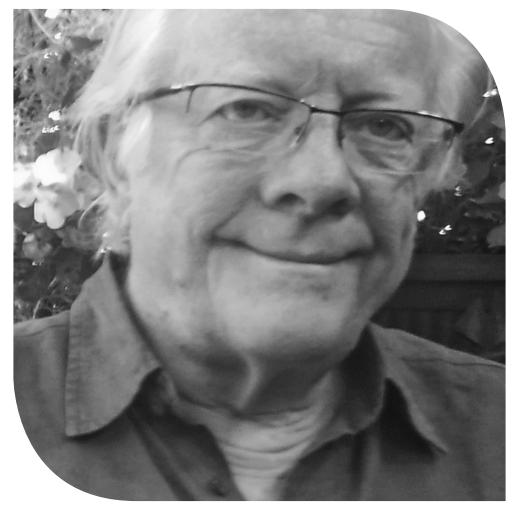




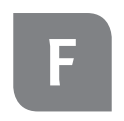

INTERVIEW

\title{
The killing fields of inequality
}

\author{
Interview with Göran Therborn \\ by Sofia Aboim
}

I n this brief, though illuminating interview, with Göran Therborn, we start our discussion by reviewing the key arguments of his most recent book, The Killing Fields of Inequality (Polity, 2013). In his well known sociological style and following the robust guidelines of his work, Göran Therborn brings inequality to the fore, expanding the inquiry into the roots of inequality, undoubtedly one of the key problems of our time, if not the most important. Indeed, always favouring a comparative and global perspective, Therborn's book presents us with a wide and insightful examination of the various dimensions of inequality in a rare combination of theoretical developments, historical substantiation, and empirical evidence. If exploring the causes and dimensions of inequality is of major importance in Therborn's work and in this book in particular, the strong points of The Killing Fields of Inequality rely perhaps in the author's capacity to find compelling answers to a few of the most inescapable questions about inequalities. When inequality is on the rise, as it is today, and cannot be ignored by social scientists, Therborn discusses the meanings of inequality, identifies its damaging consequences, and shows us why we should care about inequality and seek alternatives. In this interview, which was carried out by e-mail, the initial motto of the conversation evolves into an assessment of inequality-related problems, which includes conflict, the re-emergence of class as a key analytical concept, the expansion of inequalities to domains other than the economy, the restructuring of the global and globalization processes, in and beyond Europe and the West, viable alternatives to the current state-of-the-art, and the reshaping of old categories of thought.

Göran Therborn is Professor Emeritus of Sociology at the University of Cambridge (UK) and Affiliated Professor of Sociology at Linnaeus University (Sweden), as well as the current Editor-in-Chief of the journal of the European Sociological Association, European Societies. Author of many books including the classic What Does the Ruling Class Do When it Rules? (1978) and From Marxism to Postmarxism? (2008), he is one of the most cited and influential contemporary Marxian sociologists. Therborn's work is notable for his development of topics concerned with the general political and sociological framework of post-Marxism, namely the intersection between class, the state apparatus, and the formation of ideology. Defining 
himself as a civic intellectual committed to universal freedom and equality, Göran Therborn has been exemplar in combining academic relevance with critical thinking and engagement on a global scale.

*

SOFIA ABOIM The subject of your most recent book is as compelling as it is shocking. Inequality kills, you argue supported by sobering and unambiguous evidence. Inequality has for long been a key topic in your reflection throughout your career. Can you explain why you have written this book? What is the main message, what have you added to your former writings?

GÖRAN THERBORN Inequality has been an object of outrage in my life, but for a long time it was not so much a topic of reflection. The inequality produced by capitalism, imperialism, racism, and sexism appeared self-evident in its brutality. The main tasks were to understand the powers which sustained it, and to organize the fight against it. So I tried to get at What does the ruling class do when it rules?, and The ideology of power and the power of ideology. I also wrote extensively on class structures and on parameters of class struggles and class relations of power. Inequality became an intellectual problem, once the prospects of cutting it down receded, with central de-industrialization and the working class and socialist defeats of the 1980 s.

My serious thinking about inequality was inspired by a l988 lecture by Amartya Sen, whom I had met in the early 1980s, raising the question, Inequality of What?" But there came other issues on the agenda first. There was the question of Europe, no longer to be neglected by the Nordic left and by Nordic scholars, when most of the Northern countries were joining the EU in the early 1990 . European Modernity and Beyond (of 1995, updated into a $3^{\text {rd }}$, French edition in 2009) was my answer. I also got committed to write a book on a particular dimension of inequality, patriarchy, and sexism, Between Sex and Power. Family in the World, 1900-200o (2004, Brazilian edition Sexo e Poder, 2008)

Sen's work set me thinking about the multidimensionality of inequality. In that direction, I also began to read epidemiology and social medicine, the only fields in which inequalities of life and death were systematically studied. At the Sociology World Congress in Brisbane in 2002 I organized a couple of semi-plenary panels to bring this out. Expanded, it became my edited volume Inequalities of the World (2006). At Cambridge, in the mid-20oos, I started to work focusedly on inequality. The current book began as a series of lectures to my Master students at Cambridge. The somewhat later outbreak of the financial crisis suddenly brought inequality into the mass media, for a while. And everybody immediately seemed to know what inequality was, the income 
share of the top 1 per cent and the bonuses of the bankers who had produced the crisis.

Thank God for revelations, but the momentous outrage did not change anything. The caravan of financial capitalist inequality is moving on, at an unhampered speed. And all other issues of inequality remain, not only in existence but beyond conventional imagination.

My book has three main aims. First, to address fundamental theoretical problems of inequality, its relation to human difference, its multidimensionality, its social mechanisms, and the corresponding processes attacking and reducing it. Second, to provide an empirical overview of the three main kinds of inequality, historically and currently, globally, and intra-nationally. Third, to draw attention to the seriousness of inequality's consequences by highlighting its lethal effects.

SA The title reminds us of a 1984 British film about the Khmer Rouge regime in Cambodia, which immediately brings violence and death to mind. When we live in times of increasing inequalities, which forms of violence can we expect? What would be in your opinion the worst case scenario?

GT The Killing Fields of Inequality is meant to draw your attention to the fact that inequality kills. It is not just provoking violence.

The killing capacity of inequality includes:

- Sexist selective abortions and child neglect, clearly evident in post-Communist Caucasus, China, India, Pakistan, and South Korea.

- Environmental exclusion and marginalization, into barren lands, slums without sanitation, susceptibility to flooding and landslides, pollution.

- Exploitative working conditions, exposure to fatal accidents, to fires in locked premises.

- Exclusion/Marginalization from access to preventive and curative health care.

- Exclusion/Marginalization from the labour market: in Sweden in the l99os unemployment increased the risk of premature death by $50 \%$; in Finland the life expectancy of unemployed people in the l99os-200os declined.

- Subordination, degradation, humiliation: Among permanent employees of the British central government bureaucracy and among the employees of the City of Helsinki, the likely death dates follow the office hierarchy: people on the lowest rungs die first, those on top last. After controls for smoking, alcohol, and body mass.

- Unequal distribution of knowledge, of (un)healthy diet and body comportment. 
SA And how could we avoid it? Do you see signs of hope in today's world? From the Arab Spring to the formation of movements against inequality across the globe, quite a lot has been discussed. Which elements are positive in contrast with the somber tone set by inequality?

GT What little short-term hope there is comes from Latin America. The early $21^{\text {st }}$ century has turned out a moment of equality in Latin American history. How far it will go, and how sustainable it is, are open questions. However, from the first decade of the century the results are impressive, with a reduction of the Gini coefficient of ten per centage points or more in Argentina, Bolivia (-14 points 2002-11), Nicaragua, and Venezuela. In Ecuador the reduction was nine points, in Peru and Uruguay eight, and in Brazil seven (data from CEPAL).

SA You mention exclusion as the worst form of inequality. Can you elaborate on this idea further explaining the 'difference' between the different forms of inequality that you identify?

GT No, exploitation is the worst form, always morally indefensible. You have to deny it, rather than defend it. The four basic mechanisms of inequality form a scale in which the later/higher ones include the former with adding something more. Distantiation most directly refers to individuals, groups, nations running away from the rest - or falling behind. Exclusion means putting up barriers of access, membership, citizenship, fees, or ethnic/racial or gender criteria. Hierarchization refers to organizations of human life by means of superdination and subordination. Exploitation means that the privileged position of $\mathrm{A}$ is due to the contribution of $\mathrm{B}$. Because of their different moral implications you find these mechanisms (implicitly) invoked in ideologically sensitive interpretations of history. For instance, was the modern wealth of Europe due to the technical-industrial revolution in Europe (distantiation), the monopolistic practices of the European empires impeding colonial development (exclusion), the asymmetry of the Modern world system (hierarchization), or the European plunder of the wealth of their conquered colonies (exploitation). The mechanisms are not necessarily mutually exclusive.

SA What are the most dangerous threats to equality? Do you think we should fear the downgrading of democracy or be even more afraid of neo-liberal capitalism and its mechanisms of exploitation? Should we be concerned with new forms of fascism or with the economy?

GT The increasing power of capital is the main threat, It does not mean fascism, but capitalist political dictat-ship. While the popular classes are kept unorganized and divided, corporate money its tightening its grip on political campaigning 
and the political agenda. The United States is the trailblazer, where Southern states (most recently Tennessee) can offer incentives to corporate investment on the condition that no trade union is allowed, and where the Supreme Court majority has just lifted all restrictions on corporate financing of political campaigns and elections, now running into billions of dollars.

SA What is the role of ideology in the reproduction of inequality?

GT Ideology operates in three different modes, as I analysed in my book a long time ago, in terms of What Is (not), What Is Good/bad, What Is (Im)Possible? Mainstream ideology in the North Atlantic area has now acknowledged that inequality exists, and that is bad (at least rather bad). Alas, it is held that it is not possible to do much about it, given the imperatives of capital, of growth, or other pressing item on the agenda.

SA As a Marxist and left-wing scholar, what do you think is more important in the Marxist legacy? To what extent do we need to recover Marx and Marxism to interpret contemporary dynamics of inequality?

GT Two things, above all, are important. A focus on the dynamics and mutations of capitalism. Here Tomas Piketty's Capital in the $21^{\text {st }}$ Century is a most welcome important contribution, although I think he misses dimensions of inequality and the complexity of its historical development. Secondly, in all fields of social and cultural study, the Marxian dialectical approach is crucial, i. e., the attention to tensions, contradictions, and conflict.

SA You state very clearly that sociology has not been concerned with inequality. Some would argue that you are narrowing down sociology to mainstream functionalism, for instance, and that you have ignored what is commonly called conflict theory. How can you defend yourself from such criticism?

GT Sociologists have certainly studied various aspects of inequality, and in some branches inequality is even central, as in investigations on racism and sexism/ patriarchy. However, I think it is telling that the ISA (International Sociological Association), among its more than 50 research committees, has not one on inequality. The nearest there is, is one on "stratification", a functionalist geological import. An impressive technical sophistication has been to measure the liberal problematic of "mobility" or "inequality of opportune", but hardly anything on inequality killings and stunting of lives.

SA Your theory of modernity has presented an alternative to famous proposals, such as that from S. N. Eisenstadt and his notion of multiple modernities. Why is the concept of entangled modernities more operative? 
GT Eisenstadt made a valuable attempt to free himself from the unilinearism of functionalist modernization theory. But "multiple modernities" is a cop out, without any analytical edge. It is merely recognizing that not all modern societies look like the United States. I have argued, most recently in O Mundo (Brazilian edition 2014) that modernity would be better seen as a specific, singular time culture, to which there have been several historical pathways in the world, which may be entangled, and which have enduring effects on modern societies. In other words, I am trying to develop a global explanatory theory of modernity and its variants.

SA Do you think that historically and socially we are on the verge of a paradigm shift toward a different era? Why?

GT I do not see any clear evidence of it. But we should probably expect one. The classic canon of sociology was formed by the dichotomies of social change envisaged by male European authors of the lith-early $20^{\text {th }}$ century. Contemporary, increasingly global, and multi-faceted sociology is likely to challenge that.

SA Against this backdrop, which future can you envisage for Europe?

GT Europe will limp along, but it has lost its élan. Its handling of the financial crisis means that it can no longer claim to be a successful social model. Its provocation of the Ukrainian crisis, by intervening in favour of one half of a divided country against the other, has shown - as did its earlier participation in the economic war against Iran - that it has no legitimate claim to a project of peace, although German diplomacy is currently trying to prevent a full-scale return to the Cold War, as proposed by the Obama administration ("isolating Russia"). A key test will be the transatlantic trade negotiations, where a key us demand is a special, privileged adjudication process for corporations, making it possible for them to challenge and override democratically legislated rules, on environmental, health, and safety risks, among other things.

SA Do you think that in the near future we will have two or more Europes, with some countries - such as Portugal - being affected by impoverishment? Would you agree that the current scenario is constructed upon a very clear power hierarchy?

GT The two Europes are most likely to divide inside countries, between a prosperous "cosmopolitan" business and entertainment class, on one side, and ordinary people on the other. Sure, the EU handling of the crisis was clearly dictated by the most neoliberal north-central European power elite.

SA In your opinion, what would be the best way out of the crisis?

GT An egalitarian revolution. 
SA Finally, what do you think should be the key lesson for social scientists and the social sciences?

GT Never underestimate the pettiness of most contemporary politics - neither the pettiness of its myopia and narrow-mindedness, nor that of its inertial staying power.

Авогм, S. (2014), Interview “The killing fields of inequality”. Análise Social, 212, xLIX (3. ${ }^{\circ}$, pp. 729-735.

Göran Therborn »gt274@cam.ac.uk » Department of Sociology, University of Cambridge » Free School Lane, Cambridge, Св2 3RQ uK.

Sofia Aboim »sofia.aboim@ics.ulisboa.pt » ICs-UL » Av. Professor Aníbal de Bettencourt, 9 - 160o-189 Lisboa, Portugal. 